\title{
DONALD TRUMP AND HILLARY CLINTON'S DISTINCTIVE LANGUAGE STYLE DURING THEIR SPEECH ACCEPTANCE.
}

\author{
Mangantar Sitohang \\ A lecturer of STIBA-IEC Jakarta \\ Tohang-tantan@live.com
}

\begin{abstract}
.
This research attempts to analyze the America's President Nominees for 2017 to 2021 period, Donald Trump and Hillary Clinton's language styles during their acceptance convention nomination speech seen from Speech Acts classification. Donald Trump representing Republic Party and Hillary Clinton representing Democratic Party must have done their best to prepare their speeches in their first day campaign for all the people coming the building/hall and all American who listen to their speeches. And the fact, the situations/atmospheres in the building, seen from the video/YouTube are so interesting, entertaining, mixed emotional and touching sceneries. Those sceneries are really present not only because their beautiful musical back grounds but above all due to their speech styles relating with or covering not only about their strong claims/beliefs or assertion /descriptions about his/her opponent drawbacks but also about his/her strengths or achievement. The pledges, assertions, commitment and desires or orders articulated are also interesting to see or observe. Many of their utterances contain slippery meanings or messages. So no wonder almost all the people coming the building constantly are really impressed and give enthusiastic and supporting responses to both of them in more than one hour, and quite often they give standing applause after hearing very strong declaration, commitments, plans, vows and promises to all Americans. And apart from that, we can clearly see how each blows his/her blow his/her trumpet or how each attacks his/opponent in world class level. And for the researcher, what they have demonstrated in term of their language styles are important, educating and inspiring, therefore deserves to be observed, and for English language lecturers/teachers and students who have interests in English, this is really interesting to observe.
\end{abstract}

Key words: speech act, distinctive language style, utterances and slippery message 


\section{A. INTRODUCTION}

\section{Background}

American convention nomination speech for their Presidency Candidates is one the most special events in American political agenda and is always awaited curiously. As the winner between the official candidates will determine the fate and the future of America. To the world, not only for the Americans themselves, this year acceptance convention speech is a lot more special than the previous ones. This should happen because of two clear facts. Americans have opened a new chapter, that is one of Candidates is represented by female Candidate, Hillary Clinton. She has defeated all male candidates from Democratic Party during pre- qualification process, and she could qualify with a convincing result.

Another fact that makes this year convention nomination speech more special is the presence of her opponent, Donald Trump. Right from the very beginning, many people have raised their eye brows when he became one of the candidates representing Republic Party. Many people, not only American show their resistance to Donald Trump, as he is labelled, a controversial man. He has made some controversial statements that often make people very surprised / shocked or even get angry or offended due to his some controversial statements.

The researcher's main interest is here neither to observe how Hillary Clinton could qualify to represent Democratic Party nor to discuss why Donald Trump should get the controversial candidate label, but solely to see their language style during their acceptance of speech nomination. The researcher feels very lucky to have met and heard their speeches from YouTube. Well, listening to English news / English speech is one the researcher's hobbies, as it can refresh and enrich his insight. English speeches / English news can of course be found / heard from Radio or TV, but the researcher chose YouTube as the source of the English speech to be observed. Donald Trump and Hillary Clinton's purpose is exactly the same during their speech that is to convey official declaration for acceptance nomination and at the same time to start campaigning. They must have done their best for that very important moment; such what issues to raise and how to improve /solve them. And those can perhaps give the people's preference for the up-coming American election. The researcher has no capacity or competence to comment on their speech contents of course, but the researcher's top priority is to observe closely Mr. Donald Trump and Hillary Clinton's distinctive language style in declaring their nomination convention speech as US President Candidates. One of two must be elected, and will automatically become as US President, a President of a super power country, and their language color might have contribution to his/her win, perhaps, the world is watching, the world is waiting. 
Of course, it is during their acceptance nomination speech, they both tried their best to express their grateful and sincere gratitude and empathy to their audience/people and at the same time also to influence or persuade them by making/showing assertions, describing their commitments, and making or describing many issues to attack his/her opponent or showing his/her achievement $\mathrm{s} / \mathrm{he}$ has done in America.

At the beginning part of their appearance at the podium, each receives very warm welcome from their guests/crowds. Their gratitude and greetings to their people look very interesting, when accepting nomination and declaring his/her readiness for the US President Candidate. And the facts all the people coming the building look very enthusiastic and excited in hearing the messages, $\mathrm{s} / \mathrm{he}$ is about to convey or deliver. From the researcher's point of view, both tried to impress and convince the American people that s/he deserves to be elected on the Election Day and lead America, a superpower country.

And the facts, what they have shown/demonstrated during their convention nomination speech did not only to welcome and express gratitude to the people supporting him/her but, above all also to suggest or guide their supporters to elect $\mathrm{him} / \mathrm{her}$ in the Election Day. The way each directs and influences/persuades them is so rich or colorful. How each blows his/her trumpet or makes claims, about his/her achievements at the same time, each also shows his/her opponent weakness or failures also contains colorful languages that also often contain slippery messages/meanings. The way Donald Trump labels himself, and the way Hillary Clinton labels Donald $\mathrm{T}$ or and herself is interesting to note from speech acts angles.

In a nut shell, to many people the content of their speech /programs are their top concern but for the researcher, it is their language color during their speeches, and to reiterate, their goal is the same, to declare their acceptance and each articulates differently, with his/her own way.

\section{Problem Formulations:}

1) How are their speeches like seen from Speech Act Classification? Or what dominant Speech Act Classification can be found in each candidate's speech?

2) What types of modalities does each employ showing their pledges, promises, commitments and who employs more various modalities on their speech?

3) What slippery assertions/statements does each convey in their speech? 


\section{Theoretical Framework}

\subsection{Language}

Language is something taken for granted. Yet without it government could not operate, business would cease trade could not be carried on, and science industry would be hopeless tangle. In fact, without language most human activity would cease.

\subsubsection{Functions of Language}

Among many functions of language, the researcher quotes only relevant functions to this topic:

a. The instrumental function, meaning language existence is not only to obtain goods and services but also to communicate preferences, choices, wants and needs, very often it's situational.

b. The regulatory function that is language's presence is to supervise and to control behavior of other people through language use.

c. The representational function that is the use of language is to explain something, convey messages, making statement, presenting all facts and knowledge, describing and reporting all realities as what people really see.

d. The interactional function, the uses of language to have interaction with others, to develop a plan or maintain a play/group activity, and this interactional communication will of course need knowledge such as slang, jargon, cultural values, idioms etc., so that natural interaction can exist contextually.

e. The personal function, that is to give someone to express his/her feeling, emotion, condition etc., and normally some body's character / personality can be seen from his / her personal language function.

f. The heuristic function, the use of language is explored and gain / find out new knowledge and the use of this function is normally made in questions that should else be answered as well.

g. The imagination function, the use of language for fiction such as creating, poems, story, novel, etc. 


\subsection{Speech Acts}

Language presence is mostly found in oral forms; such as in conversation/dialogue or monologue, or in speech etc., and their needs vary and people normally can make their own interpretation from the utterance or speech they have just got/heard. But if seen from speech act classification, the content or the message conveyed could be clearer to the hearers (people).

As the basic unit linguistic communication, Speech Act, the production of what is said within performance of an action shown via utterance, can provide a particular meaning. And Austin (1962) argues that in producing a speech act, speakers perform three kinds of acts simultaneously, elocutionary act - the act of saying/uttering something in a given language, illocutionary act - the act of performed in saying something, such as making a statement, declaration, request etc. and elocutionary act - the act performed by saying something, that is the effects on the hearers produced by the illocutionary act - eq. convincing, persuading etc. forms. And Searle gave taxonomy/classified Speech Act into five.

\subsubsection{Speech Act classifications}

a. Commissive Speech Act, this relates to the speaker's commitment, plan, intention, promise or vow s/he has to do/achieve in the future example : "We are going to build wall".

b. Assertive/ Representative Speech act, the speaker's report, complaint, claim, statement, assertion etc., ex. "We have the most powerful military".

c. Directive Speech Act, the speaker's wish to ask, advice, order, request, recommend, invite or beg the listeners or audience about something.

d. Expressive Speech Act, this has to the speaker's way to: welcome, thank, apologize or deplore, condole, praise, blame, forgive, pardon. Ex. of thanking or welcoming: "what a remarkable week it's been!'.

e. Declarative Speech act, this relates to the speaker's way to pronounce or declare something or condition/situation. Or the world is in some way no longer the same after something has been said.

\subsection{Language style}

Normally, everybody has their own way when talking or giving speech, they will choose the best way they can to deliver/convey to their target people. So language style, the choice of words/dictions, phrases, utterances, sentences or particular characteristics may have to do with the choice of figurative language, paradox, sarcasm, cynical, irony slogan, and motto, credo and so on to make their messages to their target people look more accurate, lively or powerful. 
a. Figurative

There are people stating or describing things, conditions or situations straight to the points by employing words having only denotative meaning, which we often think result in effective and efficient result, and that's fine, but there are also many people when sending message they tend to use words that give new insight, new greater effects and stronger image or new perspective to the hearers or listeners called figurative languages. And figurative language or figurative speeches cover many, depending on the needs or purposes of the utterance, speech, or text.

b. Slogan

Beside figurative language that can become their tools in speech campaign, candidates are often known from their simple and catchy words or catchline/strap-line o/ tag-line which are called as slogan. And those short and easily remembered words, phrases or sentences are especially designed to advertise / promote their ideas, and of course they are hoped to attract and impress potential voters' attention. And normally the candidates must have had/hired political consultant to design powerful and attractive ones, so they sound up-todate or relevant to current condition.

c. Motto

The people might not be satisfied with the above aspects to the candidates; they need to know the candidates' brief statement to show/express their lives goals or lives goals, their beliefs or aims and shortly defined as Motto. Because all these factors will be seen as guiding steps to do their action in achieving their visions.

\subsection{Modality}

Modality is cover term for devices which allow speakers to express varying degrees of commitments or belief, it can also signal a particular attitude on the part of the speaker to the proposition expressed or situation described. In words, it can function to show/express the speaker's judgements, stance or attitude on the truth of the proposition the speakers utter. Modality has to do with two kinds; Deontic modality, relates with obligation and Epistemic modality is concerned with possibility. And modality is normally used in;

Nouns like : duty, obligation, probability, likelihood

Adjectives like: necessary, possible, likely.

Adverbs such : as obviously, probably, perhaps.

And Halliday classifies Modality or Modal Verbs as follows;

1. High : must, ought to, need to, have to, is/am/are to 
2. Median : will, would, shall, should

3. Low : may, might, can.

\subsection{Semantics and Pragmatics}

People's utterances normally mean for something, when the meaning coming from the utterances relate with linguistic knowledge itself, then it's part of Semantics, that means, the meaning shown in the sentence or utterances, can be related with reference, or sense relation or often put SP, Semantic Paraphrase. And besides that, in analyzing meaning, it can also be related with Pragmatics, branch of linguistics that studies the factors that govern our choices of language in social interaction and the effects of our choice on others, or it is the study of how utterances have meaning in situations and normally to show equal meaning we put PP, Pragmatic Paraphrase. Meaning analysis might have to do with entailment that is the relation between two or more utterances/sentences conveyed by the speaker. And meaning analysis related with Pragmatics can also be seen from Presupposition, meaning that the speaker assumes the receivers/listeners already know the message the message is about.

In short, to grasp utterances/sentences' meaning, should be seen from various sides angles, depending on the context or situation constraints, no wonder, we often see; SP, Semantic Paraphrase, Pragmatic Paraphrase, Entailment, Presupposition aspect from the utterance/sentence presence.

\section{6. Methodology}

In this study, the researcher uses descriptive method using discourse analysis to describe the theories related to the research topic.

\section{B. FINDING AND DISCUSSION}

His acceptance speech is opened by his own daughter, Ivana, and After that Donald appears on the stage, welcoming his supporters and says "thank you /thank you very much' about five times for the very warmth welcome he receives accompanied with responsive gestures, he then greets the people / audience with intimate expression/greeting. In the fourth minute he said "Friends, Delegates and Fellow Americans I humbly and gratefully accept your nomination for the Presidency of United States. And he reminds the people coming about his disbeliefs when he started his candidate process from the beginning, meaning Americans/people prediction for his success representing Republic Party is 
something unbelievable. He articulates with strong raising tone, expressively and on the third minute, he proudly accepts the nomination. The he continued "we will lead our party back to the white House, and we will lead our country back to safety, prosperity, and peace. We will be a country of generosity and warmth. But we will also be a country of law and order.

Then he makes many assertion and statements, saying in USA there are many bad situations or conditions such as the attacks on the police, terrorism, violence on the streets and chaos in the community, unemployment, increasing poverty, injustices, and victims of shootings. To him the present government fails to protect and defend the lives of the citizens, and full of lies. He presents or describes all mentioned above, in details and in many various utterances or expressions which often contain sarcasm, or paradoxes sentences/expressions that make people or audience shocked or surprised about his opponent, as she is still closely-linked with the present government/incumbent. So all the accusations he addressed to his opponent are in various utterances.

The predicate Donald Trump attaches to Hillary Clinton also sharp, starting from her position as a; Senator, First Lady for 8 years and as a Secretary of State 2009 to 2013. The labels he gives are not less sarcastic and paradoxical. Such as incompetent, weak, careless, puppet and has bad track-record, as she is closely link with Barrack Obama, the incumbent and her husband Bill Clinton.

In part of his speech, Donald Trump blows his trumpet, in very confident and expressive way he said "I alone can fix all the problems", it means he the one and only who can understand all the problems and have empathy. And apart from that, he also makes many good and beautiful promises or plans. In solving the problems by America, Mr. Donald Trump shows or describes his commitments by employing many modalities in his speech which makes his language or speech really great and colorful as well. And not less interestingly, besides all those modalities he uses, he also empowers his words by using some figurative language, showing evocative meaning. And before ending his speech also expresses amazing compliments to his wife, children, brothers, and sisters and to both his late parents, which is very different from his opponent, she at the very beginning, greets her family. But the essence of all the utterances he uses in every speech or utterance above is: to convince or influence/persuade the audience. And people coming to come to the building or who watch/see. Some might feel satiated or convinced that he is the most suitable candidate and deserves to be a president lead US. So he has employed many powerful words or expressions that could perhaps attract potential American voters, that's his purpose. 


\section{Classifications or Percentage}

Mr. Trump spent almost 70 minutes when giving his speech, and it contains about 278 sentences, and the followings are proportions

180 sentences are assertive or about $60 \%$ from the total.

80 sentences are commissive or about

5 Sentences are expressive or about

5 Sentences are directive or about

1 Sentence is declarative or about \%

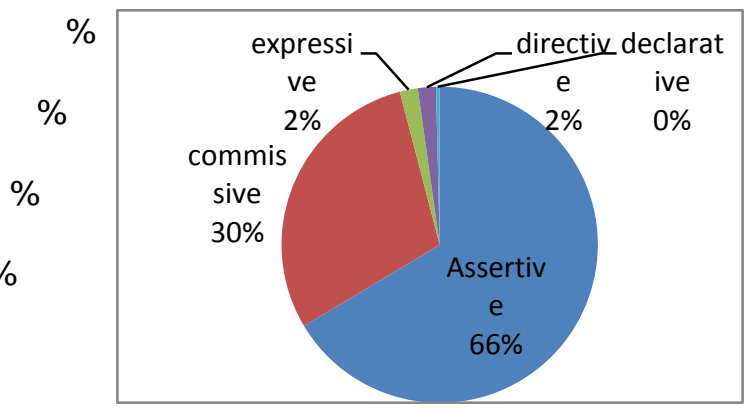

Modality presence in his speech

Will 66

Must 6

Can 4-1

Would 2

Need to 1

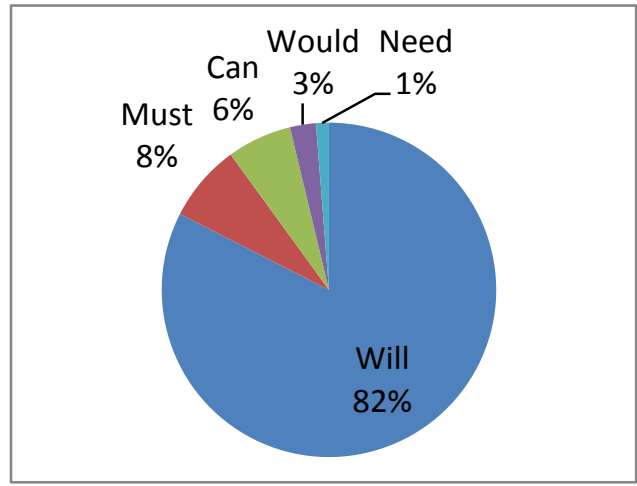

The way Mrs. Hillary Clinton welcomes and greets the people coming the building is not less attractive but a lot different from her opponent, Mr. Trump. She first thanked for the amazing welcome she received. She stated her readiness not very beginning of speech and after giving compliments to her friends and supporters the ones she knows well. She showed her pride to her daughter presence, Chelsea along with her husband Mark, and their children, Charlotte and Aidan after that she mentioned her husband, Bill Clinton. After telling how happy she is, she also thanked Barrack Obama, Joe Biden, First lady Michelle Obama, Bernie Sanders and her partner Tim Kaine.

Mrs. Hillary Clinton's acceptance of speech takes almost an hour, consisting about 370 sentences/utterances. While her opponent takes almost 70 minutes, And their language difference does not only relate with size, and duration of their speeches but more than that ; pledges, plans, modalities, how she labels 
her opponent, how she labels herself, what her strong points and achievements look interesting to observe.

This is how she begins "Thank you the amazing welcome! And Chelsea, thank you, I am so proud to be your mother and so proud of the woman you have become. Thanks for bringing Marc into our family, and Charlotte and Aidan into the world. And Bill, that conversation we started in law library 45 years ago is going strong.....etc. And in the eighteenth minute, she declares; and so with humility...determination... and boundless confidence in America's promise.... That I accept your nomination for the President of the United States, and she implicitly questions her opponent capacity and competence by saying "Sometimes people at this podium are new to the national stage, as you know, I am not one of those people. The she presents briefly her positive tract record "I have been the first lady. Served 8 years as a senator from the great State of New York. I ran for the President and lost. The I represented all of you as a Secretary of State. But my job titles only tell what I have done...etc.

She then opens her opponent business tract record "But Trump, he is a businessman. He must know something about economy.... In Atlantic City, 60 miles from here, you'll find contractors and small businesses who lost everything because Donald Trump refused to pay the bills... not because he couldn't pay them, but he wouldn't pay them.

Then she continues giving bad labels by saying ".as the one who only gave empty promises, implants hatred and fears to each other and divides unity, one who limits people's freedom, equality and opportunity. Someone who is self-center or selfish, does not practice what he says, has bad business track record, temperamental and so on. She articulates all those very expressively to make all the audience coming to the building feels clear who actually he is. To say "NO" to Mr. Trump and to support her.

As mentioned earlier, Hillary Clinton spent almost 60 minutes and her acceptance nomination speech, and roughly her speech consists of 375 sentences/utterances and the proportions are as follows;

$\begin{array}{ll}\text { Assertive } & 222 \text { sentences. } \\ \text { Commissive } & 50 \text { sentences. } \\ \text { Expressive } & 25 \text { sentences. }\end{array}$

Directive 24 sentences.

Declarative 1 sentence.

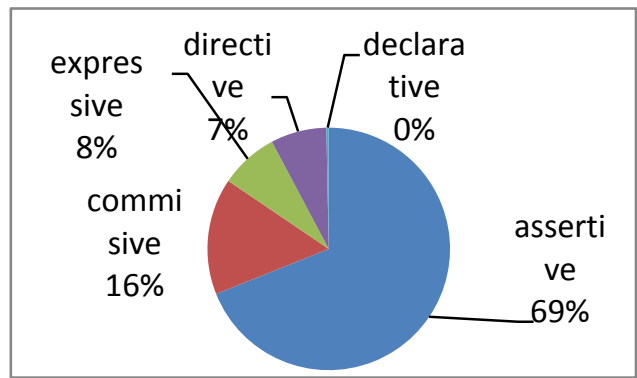


In presenting her commitment when elected, she employs many modalities in her speech.

In here are the percentages in her speech;

Will 31, can 24-3, should 8, would 3, could 3, have to 3, must 3, might 1 .

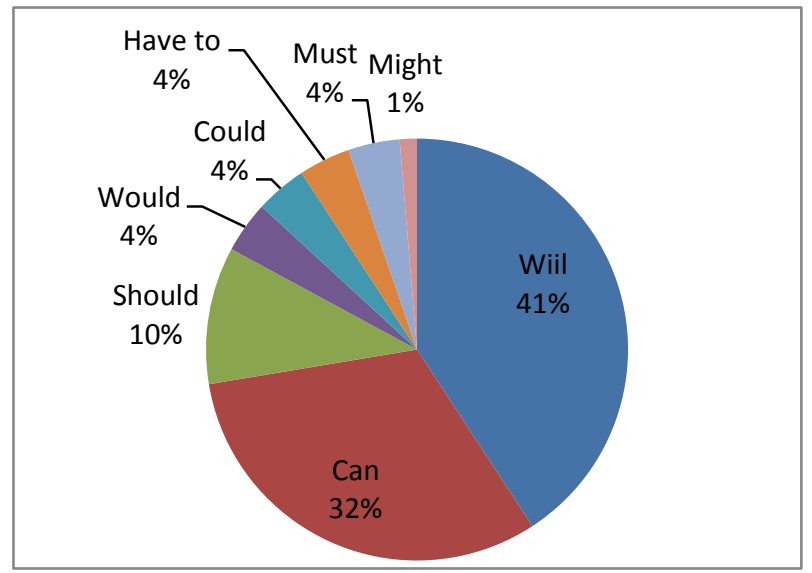

a. How their speeches are like.

Having longer time when giving speech, doesn't mean can make more assertions, directives, expressive etc. The fact Hillary Clinton's language is not only more various/colorful than Donald's, especially in the opening part but she made a longer expressive utterances in showing her gratitude compared to Donald Trump's. Her speech is a lot more dominant in all classification except for commissive. For this part Donald's pledges/promises relate with commissive are a lot more compared to Hillary Clinton's.

On third minute of his speech, Donald Trump directly expresses his willingness/readiness to accept his nomination, with Declarative Sentence, containing verb phrase after Subject "I" ( humbly and gratefully accept) and he then request his supporters to defeat his opponent, Hillary Clinton so that their party, Republic to lead America from the White House.

His speech is dominated by Assertions (Assertive classification, 182 sentences/utterances) relates with accusations/claims that Hillary Clinton's ally, Barack Obama makes Americans conditions worse than ever before, but many of his assertions or strong claims are concerned with his competence and capacity to solve all the problems faced by America and make better prosperity, safety, peace for all Americans. And among many Assertive three of them are paradox, as satires or mocking to Hillary. 
For commitment and pledges, he uses around 90 commissives and the modalities he uses for his commitments are; will 66 , must 6 , can 4 , would 2 and need to 1 .

The next classification that appears after Assertive and Commissive is Expressive consisting of five (5) sentences/utterances, that is when he thanks the guests and his family and there are 4 Directive, when he asks his supporters to defeat his opponent and to bring back Republic to the White House and to see some the realities in their country, and there is 1 declarative, When declaring his nomination.

All the figurative language, paradox appears in Assertive, showing his opponent weakness and his strengths, these are all his language style/color that can be seen in about 70 minutes nomination speech, containing around 274 sentences.

When Donald Trump spends 10 longer during nomination speech, or Hillary Clinton spends 10 about minutes shorter, but roughly Hillary Clinton's speech content is a lot bigger/longer (consisting of 370 sentences/utterances), so seen from duration and content, very different, his speech duration is 10 minutes longer, but Hillary's utterances/sentences are about 88 utterances longer.

Hillary makes a lot longer expressive utterances in her opening while welcoming all her supporters, expressing praises to her family first. She expresses her acceptance in the twentieth minute, containing with Prepositional Phrase plus Noun Phrase Opening (with humility and boundless confidence, I accept your nomination)

\section{b. Types of Modality Each uses}

In conveying their commitment to their supporters or to all American, each mostly uses modality or modal verbs. There are 80 utterances Mr. Trump uses in presenting his plans or promises to make America's condition much better. The most often modality he uses is medium modality type. There are two kinds of medium modality will 55 times, would 2 followed by high modality type, and there are two kinds: must 5 times, and need to 1 , and the rest, Low Modality type can 4 times.

From about 370 utterances/sentences Hillary Clinton makes, 72 contain modalities, although she makes fewer than her opponent, but the modality she uses, is more various, here are they: medium modality type is also the most dominant, consisting 31 will, 8 should and 3 would, followed low modality type 
21 can, 3 could and 1 might and the rest high modality type consisting 3 must, and 3 have to

\section{c. Slippery meaning.}

Many of their utterances are slippery, meaning their sayings can be seen from many different angles such as; Pragmatics (Pragmatic Paraphrase), Semantics (Semantic Paraphrase), Entailment, Presupposition etc.

C.1. Slippery messages from Mr. Trump

As stated earlier that both candidates often make assertion, statements or claims that have slippery meanings, that is the messages she/he delivers are very interpretative, and here are some from him :

1. a. I alone can fix alone

1. b. PP: I am the best candidate who understands all the problems and can give the right solutions to overcome them.

2. a. I am the law and order candidate.

2. b. PP: In my leadership I will always uphold law and order.

3. a. I am your voice.

3. b. PP: I will always listen your needs and meet them

4. a. I am going to make our country rich again

4. b. Presupposition: America used to be rich/ America is poor now

5. a. I will make individual deals with individual countries.

5. b. PP: I will create freedom atmosphere for business

6. a. He (His VP Candidate, Governor Mike Pence of Indiana) is a man of character and accomplishment.

6. b. SP: My vice President has shown great result in his career.

7. a. I have no patience for injustices, no tolerance for government incompetence, no sympathy for leaders who fail their citizens.

7. b. Entailment: The present government is incompetent, and fails to handle the problem and there are injustices in America.

8. a. We will lead our country back to safety, prosperity, and peace. 
8. b. Presupposition or Entailment: No more safety, prosperity and peace in America now.

9. a. We will be a country of generosity, warmth, but we will also be a country of law and order

9. b. Presupposition or Entailment: The leader is not generous to his people. Law and Order are not upheld yet.

10. a. There will be no lies.

10. b. The present government's ally is full of lies.

And the followings are his to about Hillary Clinton:

11. a. This is the legacy of Hillary Clinton: death, destruction, and weakness. (Paradox)

11. b. PP: Hillary has always failed in her career

12. a. Her single greatest accomplishment may be committing such as an egregious crime and getting away with it. (Paradox)

12. b. Entailment: She once did crime and she was irresponsible

13. a. She is the puppet.

13. b. Entailment: She is not independent.

14. a. She is extremely careless and negligent.

14. b. SP: She is not an alert person

15. a. She is incompetent.

15. b. PP: She totally does not deserve to be a US President

16. a. She has bad tract record.

16. b. SP: She was not successful in her career.

17. a. We will build wall.

17. b. PP: We will impose restrictions to some people (?). 


\section{d. Hillary Clinton's slippery message.}

After welcoming her supporters, she gives quite long expressive greeting to her family (her daughter, Chelsea and Chelsea's husband and their children, her husband Bill Clinton) at the very beginning and to her close allies as well. This might remind American people implicitly that their marriage is always in harmony and never get divorced, which is very different from her opponent.

e. Here are other Hillary Clinton's slippery messages.

1. a. Your cause is my cause.

1. b. SP: We have the needs

2. a. We will not build a wall

2. b. PP: There won't be any discrimination in my administration.

3. a. My families were builders of different kinds.

3. b. PP: My family has made significant contribution to this country

4. a. No one gets through life alone.

4. b. PP: It needs strong unity to succeed.

5. a. When there are no ceilings, the sky is the limit.

5. b. PP: I will try to respond your progressive needs

6. a. How to break through the grid lock in Washington.

6. b. SP: We need to modify the rules to get things done easier

7. a. The choice we face is just stark when it comes to national security.

7. b. PP: National security is the top priority

8. a. American strength does not come from lashing out.

8. b. PP: Hostility makes weak us

9. a. Let's put ourselves in the shoes of police officers, young black Americans and Latinos men

9. b. SP: we should be able to show sense of sympathy and empathy to other people

10. a. You have to stand up to bullies.

10. b. PP: We have to face the criticisms

11. a. planting seeds in the garden you never get to see.

11. b. PP: It needs constant attention to maintain good results

12. a. And we begin a new chapter.

12. b. SP: Let's begin/start new period 
13. a. Out of many we are one.

13. b. SP: Unity makes strong.

14. a. I will carry your voices and stories with to the White house.

14. b. Presupposition: Your needs will be responded.

15. a. Do all the good you can, for all the people you can, in the ways you can, as long as ever you can.

15. b. SP: Always try to do any good things to all people with best ways

16. a. People who let me into their lives, and become part of mine.

16. b. SP: When we share the same interest, we are one.

17. a. Your cause is my cause.

17. b. SP: Your concern is also my concern.

\section{Conclusion}

In accepting their nomination, each demonstrates their uniqueness in their speech. In his acceptance speech, Donald Trump expresses his acceptance from the very beginning (on the third minute) of his speech and followed by sharp attacking messages to his opponent. His utterances / dictions tend be rather harsh, rude or even provocative, more straight to the point (no wonder he gets controversial predicate) but that might be part of his strategy to give powerful or strong pressure to his opponent. It is also very clear that he confidently presents more big promises than his opponent does.

Hillary on the other hand does not directly express her acceptance in the beginning of her speech, but after 18 minutes welcoming and showing her gratitude to her supporters, then she conveys her acceptance. She employs moderate diction or utterances with quite soft utterances. The modality she uses is more various to show her pledges / plans or visions. But even though with soft style, she articulates every utterance very expressively If Donald's speech contains many hatred, fears, hostility utterances, Hillary's does not. And perhaps that's part of their distinctive style to grasp big result, that is: to give preference for all Americans, and again the world is waiting and watching. And people might always remember their words. 


\section{Refenrences}

Akmajian, Adrian, Richard A. Dermers, and Robert M. Harnish. (1990). Linguistics, an Introduction to language and communication. United State : Halliday Lithograph.

Carter, Ronald and Paul Simmpson. (1995). Language, Discourse and Literature. London and New york: Routledge.

Cruse, Alan. (2004). Meaning in Language : An Introduction to Semantics and Pragmatics (Second Edition). New York : Oxford university Press.

Gregory, Howard. (2000). Semantics. London and New York : Routledge.

Hebron, Malcolm. (2004). Mastering : The language of literature. New York : Palgrave Macmillan.

Hurford, James R. and Brendan Heasley. (1983) Semantics : a coursebook. New York : Cambridge University Press.

Kenworthy, Joanne. 1991. Language in Action : An Introduction to Modern Linguistics. New York : Longman

Kreidler, Charles W. (1998). Introduction English Semantics. London and New York : Routledge.

McCarthy, Michael. (2000). Discourse Analysis for Language Teachers. New York : Cambridge University Press.

Peccei, Jean Stilwell. (1999). Pragmatics. London and New York : Routledge.

Radford, Andrew et all. (2009). Linguistics an introduction (Second Edition). New York : Cambridge University Press.

Richards, Jack C., John Platt and Heidi Platt. (1992). Longman Dicionary of Language Teaching and Applied Linguistics. England : Longman.

Saeed, John I. (2003). Semantics. USA : Blackwell.

Todd, Loreto. (2000). An introduction to linguistics. England : York Press. 


\section{INTENTIONALLY BLANK}

